\title{
Nigeria takes the initiative in African science
}

Alison Abbott

Nigeria has set up a national scientific advisory council and is planning to help fund the African Academy of Sciences (AAS) raising hopes that the country will provide badly needed leadership for science in Africa.

The developments follow the 1999 election of President Olusegun Obasanjo, which ended 16 years of military rule in Nigeria.

After the announcement last month of a US\$94-million satellite programme (see Nature 412, 110; 2001), Obasanjo said that Nigeria would donate US\$5 million to a newly created endowment fund to support the AAS, a pan-African organization based in Nairobi, Kenya.

At the same time, his government has inaugurated a new Nigerian science advisory council, comprising seven scientists, including some from outside Nigeria. It is chaired by Mohamed Hassan, a Sudanese mathematics professor, who is also president of the AAS.

Nigerian science and technology minister Turner Isoun says the decision to fund the AAS is "the most strategically enlightened decision the government has made" - mainly on account of the academy's role in increasing scientific capacity throughout Africa.

But Isoun says that the decision will ultimately be in Nigeria's own interest. Nigeria has one of the strongest scientific communities in Africa, and is a prime beneficiary of the AAS's fellowships and programmes. Of the 104 fellowships that the academy has so far distributed to young African scientists, 28
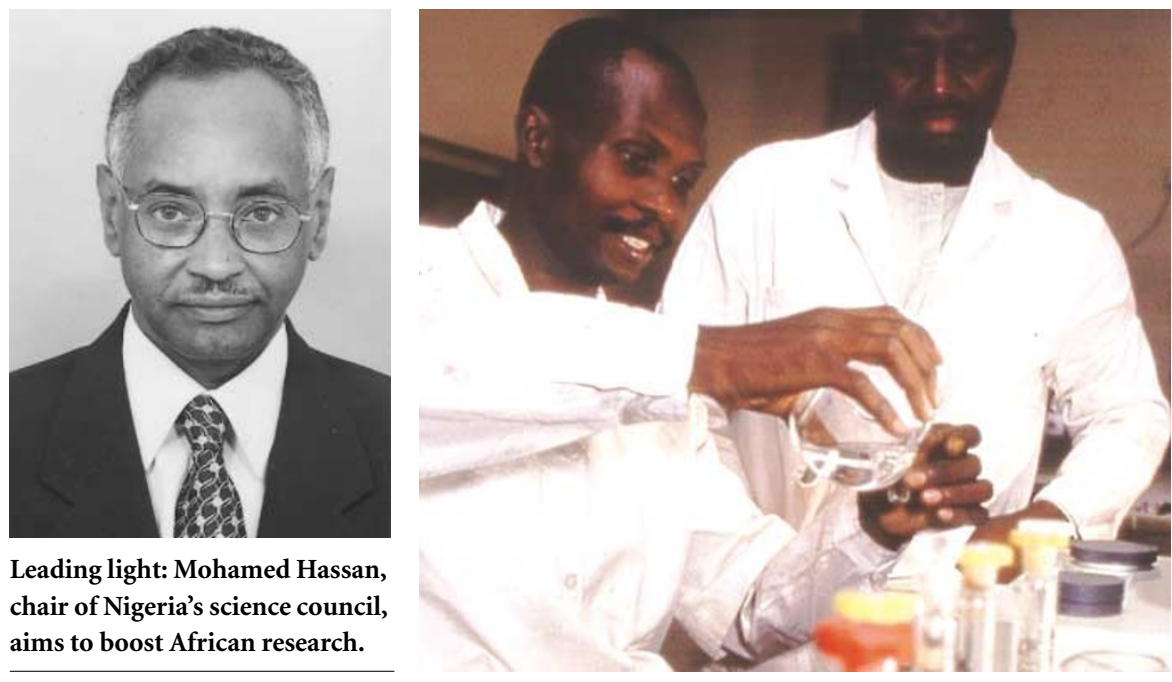

were awarded to Nigerians.

Isoun also defends the satellite programme, which had been criticized as overambitious. "It is not right that Africa should be 'sentenced' to appropriate technology," he says, arguing that Nigeria should be able to solve its own problems rather than "buying information from other countries".

At the moment Nigeria spends little on research - although no reliable figure has been published, the total is probably less than $0.5 \%$ of gross national product. But the prevailing mood is such that a large spending increase can be expected, Isoun says.

Nigeria is the first country to commit money to the endowment fund for the AAS, which was set up in 1985 to promote science in Africa. As well as electing members, of which it now has 150 , the academy also publishes a journal, Discovery and Innovation, and runs projects intended to build scientific capacity in Africa.

Initially, the AAS was supported by donations from large US charities, including the Rockefeller, MacArthur and Carnegie foundations. Now most of its support — around US\$1.5 million per year - comes from the Swedish development agency Sida. "We set up the endowment fund because we need a stable, independent source of financing," says Hassan. The AAS now plans to lobby South Africa and other African countries for permanent support.

http://www.oneworld.org/aas

\section{Feminized fish encourage Japan to test pollution links}

\section{David Cyranoski, Tokyo}

A comprehensive search for a link between pollutants and the appearance of 'feminized' male fish is being considered by Japan's National Institute for Environmental Sciences (NIES). A decision is expected later this month.

Recent research has shown that certain male fish in the seas around Japan have physiological properties usually found in females. For example, some males produce high levels of vitellogenin, an egg-yolk protein, and others even make oocytes precursor egg cells - in their testes.

Some researchers suspect that these problems are due to chemical 'endocrine disrupters', which at low doses can interfere with hormones. But most of the evidence for this comes from apparent correlations between the presence of feminized fish and heavily polluted areas. Little progress has been made in identifying the molecular

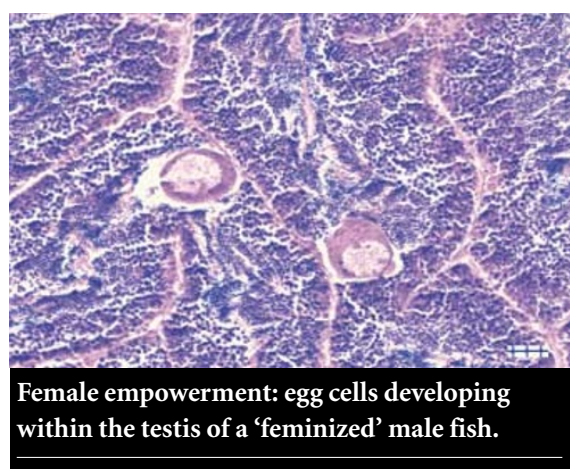

mechanisms and chemicals that are to blame.

Some scientists - as well as chemical manufacturers - dispute the existence of the endocrine-disrupter effect, regarding it as an excuse to regulate hundreds of chemicals without evidence that they cause harm.

The fact that some fish naturally switch sex further confounds the problem. "We need caution before jumping to a conclusion that something is abnormal," says John Sumpter of Brunel University, UK, who pioneered a study of intersexed roach. "The evidence linking cause and effect is slim."

But over the past couple of years, Japanese studies have indicated that the effect is widespread."We are seeing an effect in a variety of fish," says Shinya Hashimoto, an environmental chemist at Shizuoka University.

Researchers say that a comprehensive study could also help to establish a database for pollution monitoring. "It could be a valuable measure of relative pollution over the areas," says Takahiro Matsubara of the Fisheries Research Agency in Hokkaido.

The NIES is scheduled to complete a feasibility study this month to determine how best to carry out the proposed investigation, but budget constraints may prevent a more extensive study, officials say. 